\title{
„Koukala jsem na to, jak si hrajou a mluví na sebe řečí, kterou vůbec nevnímám“: Jinakost u dětí s migrační zkušeností
}

\author{
Nad’a Kabancová, Kateřina Machovcová
}

Univerzita Karlova, Pedagogická fakulta

\begin{abstract}
Redakci zasláno 15. 2. 2018 / upravená verze obdržena 20. 5. 2018 /
\end{abstract}
k uveřejnění přijato 20.5. 2018

\begin{abstract}
Abstrakt: V článku si klademe za cíl předložit zkušenosti žáků a žákyň s vnímáním vlastní jinakosti ve školní třídě. Konkrétně se zaměříme na porozumění zkušeností 1,5 generace mladých imigrantů z Ukrajiny. Naši respondenti, v současné době mladí dospělí, se v rozhovorech zabývají svou zkušeností se začleňováním do české společnosti. Pro předkládaný článek se soustředíme na období mladšího školního věku. Výzkum vycházel z provedení rozhovorů se čtyřmi respondenty, jimiž byly mladé osoby ve věku 24-29 let žijící v České republice, které se do České republiky přistěhovaly z Ukrajiny ve věku od šesti do devíti let. Rozhovory byly zpracovány pomocí tematické analýzy (Braun \& Clarke, 2006). Cílem předkládaného textu je detailní analýza toho, jak vnímali sekundární školní socializaci s důrazem na utváření jinakosti a stejnosti ve vrstevnickém kolektivu. Analýza vybraného období koresponduje s časovou osou postupného začleňování do české společnosti od prvotního „nárazu“ po zvládnutí a vyrovnání se s nároky osobní situace. Zaměříme se na identifikované aspekty tohoto procesu a strategie zvládání. Bohatá data získaná z rozhovorů ukazují, jakým způsobem v konstrukci jinakosti působí (ne)znalost jazyka a jaké emočně náročné zážitky spojené s vyloučením z kolektivu a izolací s sebou nese období potřebné pro zvládnutí místní řeči, u našich respondentů poměrně krátké. Ve školní třídě byly tyto děti často terčem posměchu, dokonce se objevovaly i narážky týkající se jejich inteligence - právě z důvodu nedokonalé znalosti jazyka. Rozhovory poukazují na to, že s touto skutečností nijak nepracovali učitelé, kteří by jinak mohli negativní vývoj alespoň zmírnit, ne-li mu zcela předejít. Po osvojení jazyka už bylo pro tyto děti navazování vztahů lépe realizovatelné. Pozorujeme snahu zdůrazňovat stejnost s majoritou a paralelně strategii začlenění skrze repertoár vlastních kvalit. Jako nejúspěšnější a v zásadě očekávaná se v českém školství jeví strategie asimilace, tedy splynutí s většinou (Berry et al., 2002). Neustálé přizpůsobování a adaptování se tak stává u dětí migrantů jakýmsi základem fungování v každodenních interakcích.
\end{abstract}

Klíčová slova: jinakost, norma, minorita, etnicita, migrační zkušenost 
Migrace do nové země klade na děti specifické nároky. Vytržení ze známého prostředí, proměna vztahů s nejbližšími, nároky na začlenění v nových sociálních skupinách, očekávání úspěchu ve vzdělávání. To vše samo o sobě znamená náročné úkoly a proces vyrovnávání se se všemi těmito změnami je dlouhodobý. Různé podoby a možnosti akulturace nejsou ovlivněné jen vlastnostmi a podmínkami na straně dítěte, ale i na straně hostitelské společnosti (Burman, 2008).

V naší studii analyzujeme výpovědi mladých migrantů, původem z Ukrajiny, kteří reflektují své zkušenosti se začleňováním do české společnosti. S ohledem na rozsah textu a zaměření čísla časopisu se primárně zabýváme jejich reflexí zkušeností ze školního období s důrazem na vrstevnické vztahy. Sledujeme, jakým způsobem je v procesu interakce s učiteli a vrstevníky zvýznamňována jinakost, a to zejména $\mathrm{v}$ kontextu určité zranitelnosti či podceňování, a jak dnes skrze zvládnutí těchto výzev mladí dospělí s migrační zkušeností volí cestu splynutí s normou, ale zároveň dokáží najít aspekty jinakosti, které mohou být ve vrstevnických vztazích výhodou. Širší rámec studie tvoří teorie J. W. Berryho (Berry, 1987; Berry et al., 2002) rozdělující proces akulturace na čtyři základní typy, přičemž pro nás, jak si na datech níže ukážeme, je klíčová diskuse asimilace, splynutí s většinou, a integrace, tedy udržení přináležitosti k vlastní kultuře i zapojení do kultury nové. Procesy vedoucí k marginalizaci a separaci v našich datech nepozorujeme.

Předložený článek je členěn následovně: v první části shrneme poznatky týkající se akulturace ve školním prostředí. Následuje kapitola věnovaná ukrajinské migraci do České republiky. Dále se již věnujeme metodologii provedené studie a předkládáme výsledky rozdělené do třech témat. Text uzavírá stručná diskuse a závěr.

\section{Akulturace ve školním prostředí}

Snaha usadit se v novém prostředí neimplikuje pouze faktickou změnu místa a dalších prvků, ale jedná se o psychologický proces tranzice. Berry (1987) uvádí pět kategorií změn, které lidé zažívají při kontaktu s jinou kulturou; jsou jimi: fyzické změny (nové město, ubytování, typ prostředí atd.), biologické změny (jiné jídlo, čistota prostředí, nemoci...), kulturní změny (projevující se v jazyce, politice, náboženství apod.), navázání nových sociálních vztahů a změny psychologické, které poukazují na změny postojů, životního stylu atp. V situaci konkrétního jednotlivce, který přesídlil do nové země, 
mezi sebou interagují faktory minulosti i přítomnosti. Je nezbytné na usídlení nahlížet jako na dlouhodobý psychologický a vývojový proces, během něhož lidé vnitřně zpracovávají různorodé změny, které se staly v jejich životě (de Wal Pastoor, 2015). Součástí zvládnutí migrační zkušenosti je obvykle proces zapojení do nové společnosti, kdy si jednotlivec osvojuje sociokulturní dovednosti žádané v novém prostředí, ale zároveň vyvíjí snahu o udržení kultury původní (Berry et al., 2002; de Wal Pastoor, 2015).

Škola je pochopitelně místem, kde se děti s migrační zkušeností nejčastěji setkávají s dětmi z majority a dalších minorit. Zvládnutí školních nároků je jeden z nejdůležitější aspektů zapojení do nové společnosti a celkově zvládnutí procesu tranzice (Vedder \& Horenczyk, 2016). Získání vzdělání v nové zemi není pouze otázkou formálního učení a zvládnutí daného kurikula. Je ve velké míře také otázkou zvládnutí tacitních znalostí, poznání lokální kultury, specifik, vztahů či hodnot (de Wal Pastoor, 2015). Kontakt se spolužáky a vrstevníky ve škole a mimoškolní zájmové činnosti jsou významným přemostěním do nové kultury a posilují či naopak inhibují schopnost zvládnout i další vývojové výzvy, jako je další vzdělávání či nalezení práce (de Wal Pastoor, 2017). Šance na lepší vzdělání a následně lepší zaměstnání je typickým důvodem migrace (Uherek, 2005), ale i přes vysokou hodnotu, kterou migranti často vzdělávání připisují, může být jeho dosažení velmi náročným procesem. Ztráta osobních vazeb, nejistota, vyrovnávání se s emočními nároky či traumatickými zkušenostmi, to vše může vést k problémům i selhání. Na to upozorňují např́́klad de Wal Pastoor (2015) nebo Vedder \& Horenczyk (2016). Tito výzkumníci se také shodují na tom, že role školy jako mediátora zvládnutí zapojení do nové společnosti je velice významná.

Školní prostředí je prostorem akulturace i enkulturace. Akulturace označuje změny, které jsou výsledkem kontaktu mezi různými kulturami, může být fenoménem na úrovni skupiny (strukturální změny) či jednotlivců (v zásadě se jedná o proces sociálního učení) (Čeněk, Smolík, \& Vykoukalová, 2016; Vedder \& Horenczyk, 2016). Enkulturace je oproti tomu formální i neformální proces vrůstání do vlastní kultury, osvojování dovedností, znalostí a chování, které jsou pro ni typické (Čeněk et al., 2016; Vedder \& Horenczyk, 2016). Ačkoliv se nejedná o zcela oddělené procesy, pro děti s migrační zkušeností to znamená, že se ve školním prostředí primárně setkávají s majoritní kulturou a dochází tedy k procesu akulturace, vžívání do jiné kultury. Proces enkulturace do jejich původní kultury je často odkázán do soukromé sféry, protože nastavení školního vzdělávání, at' už volbou kurikula, nebo způsobem 
výuky, typicky reflektuje přístupy majoritní společnosti a jen omezeně zahrnuje zvyklosti různých menšin (Vedder \& Horenczyk, 2016). V předkládané studii se tedy primárně zabýváme otázkou akulturace a de facto i právě omezenou možností enkulturace, tedy rozvoje identifikace s vlastní kulturou ve školním prostředí.

Berry a kol. (2002) na proces akulturace jednotlivce nahlíží s ohledem na míru zapojení do života v nové společnosti a na současné udržení náležitosti ke kultuře původní. Rozlišuje tak čtyři strategie:

- Asimilace je charakterizovaná snahou splynout s majoritní/hostitelskou společností, dochází k potlačení původní kulturní př́slušnosti.

- Integrace se vyznačuje paralelní snahou poznat novou, pozitivně oceňovanou kulturu, stejně tak jako zachovat kulturu původní, též vnímanou pozitivně.

- Separace je charakterizovaná tendencí k izolaci a stažení se do své původní kultury, která je hodnocena výše než kultura nová.

- Marginalizace znamená slabý vztah k oběma kulturám.

Výzkumy naznačují, že akulturace má vyšší šanci na úspěch, pokud je mezi majoritou a minoritou menší kulturní rozdíl, zároveň to znamená větší šance na uplatnění kompetencí, které migrující osoba získala před usídlením v nové zemi (Vedder \& Horenczyk, 2016). Někteří výzkumníci tak volají po tom, aby ve školním prostředí bylo citlivěji pracováno s procesy akulturace i enkulturace - např́iklad aby došlo ke změně přístupů od individualistických a na výkon zaměřených k většímu propojení studentů mezi sebou i mezi studenty a personálem (Campbell, 1997, in Vedder \& Horenczyk, 2016). Podle de Wall Pastoorové (2015), která se ve svých výzkumech zaměřuje na nejzranitelnější skupinu příchozích - mladistvé uprchlíky bez doprovodu, je nezbytné se hlouběji věnovat roli školy, a to nejen $v$ ohledu na akademickou podporu a dosažené akademické výsledky, ale i v kontextu jejího vlivu na psychické a vývojové procesy tranzice a zvládnutí adaptace v novém prostředí. Role školy je komplexní a zasluhuje adekvátní pozornost.

V této souvislosti tedy $\mathrm{v}$ následujících částech článku předložíme studii zaměřenou na výpovědi mladých migrantů z Ukrajiny, kteří v rámci rozhovorů také reflektují své školní zkušenosti. Nejde nám o zhodnocení (aktuálního) školního prostředí, jako spíše o popis obecnějších mechanismů utváření 
jinakosti a stejnosti $v$ této sféře. Naším cílem je analyzovat interakci s vrstevníky a učiteli a zajímá nás, jakým způsobem se ve školním prostředí vyrovnávali se svou jinakostí.

\section{Ukrajinská menšina v České republice}

S ohledem na vybranou skupinu respondentů je nezbytné přiblížit okolnosti migrace z Ukrajiny, charakteristiky této komunity v ČR a také specifickou skupinu volyňských Čechů, která je mezi našimi informanty zastoupena.

Ukrajinci jsou aktuálně nejpočetnější národnostní skupinou přistěhovalců v České republice. V současné době žije v České republice legálně celkem 109,9 tisíc Ukrajinců (Český statistický úřad, 2017).

Co se týče okolností migrace z Ukrajiny, velká vlna masové emigrace do ČR začala po rozpadu Sovětského svazu se vznikem Ukrajiny jako samostatného demokratického státu. Od té doby čelila tato země velkým politickým, ekonomickým i sociálním změnám, které měly často negativní dopady na život řady běžných obyvatel. Česká republika je pro Ukrajince oblíbenou cílovou zemí, a to hned z několika důvodů. Jedná se hlavně o důvody ekonomické, pracovní a často také rodinné. Základní motivací bývá hledání sociální jistoty, zvýšení kvality života apod. Mimo již zmíněné svou úlohu hraje samozřejmě také zjevná geografická, kulturní a jazyková blízkost obou zemí a s tím související široké krajanské sítě a kontakty. Ukrajinská migrace se vyznačuje směřováním za lepším výdělkem, které se postupně rozvíjí v budování silnějších vazeb k ČR a následné usídlení, resp. přestěhování rodiny, příbuzných či přátel (Leontiyeva, 2014). Ve srovnání s ostatními komunitami cizinců jsou Ukrajinci kulturně i jazykově Čechům poměrně blízcí. Jejich zapojení do české společnosti tak v celospolečenském měřítku obvykle probíhá bez větších problémů, na výzvy v rovině jednotlivců se zaměříme níže v našem článku.

Pro ukrajinskou komunitu je typické napojení na krajanské sítě, především bezprostředně po příjezdu do ČR, kdy krajané bývají pro nově příchozí migranty velkou oporou. Tyto kontakty si rádi udržují po celou dobu života v ČR. Kvůli zažitým podmínkám na Ukrajině a tamnímu politickému systému mívají Ukrajinci často pocit nedůvěry vưči úřadům a jiným institucím a spoléhají na pomoc blízkých a zprostředkovatelů při vyřizování svých záležitostí. Co se týče pracovní oblasti, Ukrajinci pracují ve všech ekonomických sférách. Řada výzkumů (Drbohlav, 2003; Leontiyeva \& Nečasová, 2009; Leontiyeva, 2014) ale ukázala, že vzdělanostní úroveň této komunity často kontrastuje 
s povahou vykonávané práce. Ve velké míře jde o práce nekvalifikované, zpravidla za náročných pracovních podmínek a při nízkých finančních odměnách (ve stavebnictví, v úklidu apod.).

Výše jsme se již zmínily také o skupině volyňských Čechů, kterou ted' přiblížíme. Pojem „volyňští Češi“ se užívá pro komunitu potomkủ etnických Čechů, která se konstituovala na území dnešní Ukrajiny na konci 19. století. V letech 1868 až 1880 z Rakouska-Uherska do carského Ruska postupně přesídlilo zhruba 16 tisíc etnických Čechů. Převážná část těchto Čechů se usadila na území Volyně (severozápadní Ukrajina), kde se živili jako zemědělci a řemeslníci. Impulsem byly těžké životní podmínky v původním bydlišti a zvěsti o prosperitě a úrodné půdě. Po většinu doby bylo Čechům umožněno zachovat si jazyk a kulturní zvyklosti (Vaculík, 1997). V průběhu 20. století proběhly dvě vlny reemigrace volyňských Čechů z Ukrajiny do Čech. Po druhé světové válce, v první vlně, bylo do Československa přesídleno zhruba 40 tisíc osob. V rámci druhé vlny reemigrace, tzv. černobylské vlně související s havárií jaderné elektrárny Černobyl, bylo v letech 1991-1993 na pozvání České republiky přesídleno téměř dva tisíce volyňských Čechů (Iljuk, 2016; Uherek, 2016). Praxe ukázala, že se krajané po svém př́ijezdu do ČR úspěšně adaptovali a integrovali (Ministerstvo vnitra, 2018). Svou „staronovou vlast“, jak ji sami nazývají, přijali jako nový domov. V důsledku ozbrojeného konfliktu a špatné politické a ekonomické situace na Ukrajině byla v roce 2015 zahájena třetí vlna reemigrace krajanů.

\section{Metodologie}

Kvalitativně pojatý výzkum spočíval v polostrukturovaných rozhovorech $\mathrm{s}$ předem vymezenými tematickými okruhy otázek. Rozhovory byly vedeny se čtyřmi respondenty s cílem porozumět jejich zkušenosti s integrací do české společnosti. ${ }^{1}$ Respondenty byly mladé osoby ve věku 24-29 let žijící v České republice, které se přistěhovaly z Ukrajiny ve věku od šesti do devíti let. Tito respondenti, zástupci tzv. 1,5 generace migrantů ${ }^{2}$, v současné době

Výzkum byl realizován jako součást bakalářské diplomové práce na téma Kulturní integrace a utváření identity mladých osob s migrační zkušeností na Katedře psychologie Pedagogické fakulty UK, obhájeno $v$ roce 2017.

2 Jedná se o osoby narozené v zemi původu svých rodičů, které jsou nicméně odmalička intenzivně vystaveny prostředí nové země, do které emigrovali. Je zde důležitý věk příchodu do cílové země, od kterého se odvíjí adaptační proces, který se tak může odehrávat v různých kontextech. Podle Zhoua jsou sem řazeni lidé, kteří přišli do cílové země ve věku maximálně 12-13 let (Zhou, 1997). 
mladí dospělí, v rozhovorech reflektují své zkušenosti od př́ijezdu do Česka po jejich současný život.

Rozhovory byly následně zpracovány pomocí tematické analýzy. Tato metoda pro zpracování kvalitativních dat spočívá v opakovaném čtení rozhovorů a kódování významných úseků rozhovorů, na základě kterých jsou identifikovány opakující se vzorce napříč daty a na jejichž základě jsou následně utvářena klíčová témata (Braun \& Clarke, 2006). Tematická analýza není vázána na konkrétní teoretický rámec, v rámci naší studie jsme ji využili v duchu interpretativního kvalitativního výzkumu.

Vzorek byl zastoupen třemi ženami a jedním mužem. Respondentům byla z etických důvodů náhodně změněna jména, ve výzkumu je tak zachována jejich anonymita. U dvou z našich respondentů se jednalo o typický př́íklad tzv. cirkulační migrace ${ }^{3}$, kdy v jejich útlém věku rodiče začali z ekonomických důvodů žít a pracovat $v$ ČR, zatímco oni vyrůstali na Ukrajině. Po několika letech se přestěhovali za rodiči do ČR, kde si vytvořili nový domov. U dalších dvou byla situace specifická tím, že jejich matky patří do komunity volyňských Čechů (viz výše), kdežto otec je Ukrajinec. Všichni členové rodiny obou $z$ těchto respondentů přijeli do ČR současně. Věk př́ijezdu našich respondentů do ČR se lišil. Dva z respondentů se do ČR nastěhovali v šesti letech, přičemž $\mathrm{v}$ zemi původu oba navštěvovali mateřskou školu. $V$ novém prostředí ale ani jeden z nich nenastoupil rovnou do první třídy, jak by se podle věku dalo předpokládat. Denis strávil po př́ijezdu na přání maminky rok doma, aby se učil jazyk a zvykal si na prostředí, kdežto Inna nastoupila do mateřské školy. Další z respondentů, Lídia, s rodinou přijela do Čech ve svých osmi letech a nastoupila do druhé třrídy, kterou absolvovala již na Ukrajině, tudíž ji v ČR opakovala. Poslední respondentka, devítiletá Natálie, nastoupila po třetí tř́dě, kterou absolvovala na Ukrajině, rovnou do třídy čtvrté. Všichni respondenti mají v současnosti české občanství. Tři z nich stále studují VŠ, jedna je již její absolventkou a momentálně pracuje na plný úvazek.

Výzkumné otázky, kterými jsme se ve studii zabývaly, jsou:

Jakým způsobem se ve školním prostředí děti s migrační zkušeností vyrovnávají se svou jinakostí?

Termín cirkulační migrace je často spojován s rozvojovou spoluprací a popisuje pro mnohé žádoucí situaci, kdy se cizinec, který migroval do hostitelské země, po určité době vrací do své země původu, popř. podniká cestu a následný návrat opakovaně, či dokonce pravidelně (Čižinský \& Hradecká, 2012). 
S jakými problémy se tyto děti v průběhu socializace a integrace ve školním prostředí setkávají?

V předkládané studii se tyto otázky pokusíme zodpovědět a zaměříme se na analýzu vybraných aspektů zkušenosti se školní socializací s důrazem na utváření jinakosti a stejnosti $\mathrm{v}$ interakcích $\mathrm{s}$ učiteli a ve vrstevnickém kolektivu, což bylo jedno z nejvýznamnějších témat, které se $\mathrm{v}$ rámci našeho výzkumu vynořilo.

\section{$4 \quad$ Výsledky}

Z analýzy rozhovorů, které se například týkaly života respondentů na Ukrajině, okolností př́ijezdu do ČR, subjektivního prožívání emigrace, adaptace na nové prostředí a utváření vazeb, prủběhu školní socializace a akulturace, vnímání vlastní etnické identity atd., vyplynulo množství zajímavých poznatků.

Výzkum ukázal, že samotný zážitek migrace a s ním spojené okolnosti prožívali respondenti poměrně negativně, lze hovořit o tzv. akulturačním stresu (Berry, 1997). Významnými faktory bylo narušení rodinných i vrstevnických vztahů. $\mathrm{V}$ rodině dochází $\mathrm{k}$ novým konstelacím - na jedné straně přestěhování za do té doby relativně málo známými rodiči, zároveň omezení dříve intenzivního kontaktu s prarodiči. Jsou zpřetrhány stávající vazby s vrstevníky, v novém prostředí mají být vytvořeny vztahy nové, proti kterým stojí jazyková bariéra, která jedince staví na periferii vrstevnické interakce. Tato jazyková bariéra se samozřejmě projevovala ve školním prostředí, např́́klad ve formě posmívání a nepř́ijemných poznámek spolužáků, mířeným jak k původu, tak $\mathrm{k}$ inteligenci a tak dále. Tři $\mathrm{z}$ našich respondentů $\mathrm{v}$ rozhovorech otevřeně mluví o setkání se šikanou, kterou silně emočně prožívali, což je značně ovlivnilo i do budoucnosti. V současné době respondenti svou migrační zkušenost reflektují jako zásadní událost v životě, jako velký životní zlom. Ten jim poskytl řadu možností, náhledů a také dopomohl k určité transformaci postojů, např́iklad větší toleranci k odlišnostem, tedy jakési otevřenosti jako charakteristice osobnosti.

Nyní se zaměříme na analýzu vybraných aspektů zkušenosti se sekundární školní socializací s důrazem na utváření jinakosti a stejnosti ve vrstevnickém kolektivu. Naše analýza dat v zásadě koresponduje s časovou osou postupného začleňování těchto dětí-cizinců do české společnosti od „prvotního“ nárazu po zvládnutí a vyrovnání se s nároky osobní situace. Centrálním zdrojem 
jinakosti byla u těchto dětí od počátku jazyková bariéra a s ní související omezený repertoár kontaktu s druhými. Bariéra sice postupně slábne, nicméně na jejím základě se průběžně vrství další komplikace, které vstupují do kontaktu mezi daného jedince a majoritu.

\subsection{Obavy z kontaktu s místními dětmi}

Přestože naši respondenti prakticky neměli žádnou možnost podílet se na samotném rozhodování o stěhování, tato situace se jich bezprostředně týkala a velmi intenzivně ji prožívali. $V$ rozhovorech popisovali svou prvotní nespokojenost, která nastala již krátce po př́ijezdu do ČR. Jejich nespokojenost je při zohlednění vcelku radikální sociální i environmentální změny naprosto pochopitelná. Všichni přijeli z ukrajinského venkova, charakteristického volným prostorem, zelení, dobytkem a hlavně přítomností široké rodiny a přátel, do malých pokojů ubytoven a betonových sídlišt' plných cizích tváří. Prošli si tedy významným akulturačním stresem. Do školy či školky většinou nastoupili krátce po př́ijezdu, aniž by absolvovali jakýkoli jazykový kurz či př́ípravu. Vše pro ně bylo nové.

(...) já jsem si tam jako neměla s kým hrát. Jsem seděla doma, pak jsem šla ven, neměla jsem tam nikoho, s kým si hrát, tak jsem si vždycky sedla na nějakou prolejzačku, koukala jsem, jak si děti hrajou a mluví na sebe prostě řečí, kterou vůbec nevnímám, nevím, co mi jako ř́kají... (Natália, 24 let, studentka VŠ)

V rozhovorech popisovali velkou obavu z kontaktu s druhými, a to jak ve škole, tak i mimo ni.

(...) pamatuju si, že na mě jednou jedna holka promluvila, ta mi byla strašně sympatická, a já jsem jí vůbec nerozuměla, ale myslela jsem si, že se mě ptá, jestli si chci hrát s nima. A já jsem řekla, že ne... No protože jsem se bála a nerozuměla jsem a bála jsem se asi tý interakce. No ale měla jsem z toho hroznou radost... Měla jsem radost $\mathrm{z}$ toho, že jsem na někoho promluvila, že jsem odpověděla. (Lídia, 29 let, absolventka VŠ)

Chodila jsem naštěstí na doučování angličtiny a jednou ňáký holky mi řekly jako „Do you speak English?", tak jsem řekla „Yes I do“. A to bylo všechno, veškerá naše interakce a znovu se nebavily, protože ony jako nechtěly mluvit angličtinou a já jako jsem jinak ani nerozuměla. (Natália, 24 let, studentka VŠ)

Jak je ilustrováno i na těchto konkrétních příkladech, pokusy o interakci zprvu dokonce odmítali. To, že neuměli jazyk a neměli žádného vrstevníka, 
který by jim byl oporou a mohl jim nějak pomoci se začleněním, situaci značně znesnadňovalo. $\mathrm{V}$ momentě, kdy byl druhou osobou učiněn krok k nim, se zkrátka dostavil strach a obavy z nezvládnutí situace, jež nějaký pokrok zablokovaly. Je zjevné, že za těchto okolností hrozí velké riziko dezinterpretace takovéto nebo obdobné situace jako nezájmu a neochoty komunikovat právě ze strany cizince, nikoli jako obavy ze selhání. To je faktor, který mủže proces začleňování značně pozdržet, prodloužit a zkomplikovat, protože reakce cizince nemusí být pro ostatní čitelné, neví, jak poskytnout podporu. Reakce cizince mohou reflektovat vnitřní zmatek, který prožívá, a může být pro něj i složité se ve svých pocitech vyznat.

Jakmile se ale s uvyknutím na prostředí a zejména s postupným zvládnutím jazyka bariéra prolomí a je lépe umožněno vytváření kontaktů, situace se začne jevit o poznání přijatelnější. Vytvoření a rozvoj sociálních vazeb se zdají být $\mathrm{v}$ daném kontextu velmi závislé na osvojování řeči, která je v praxi rozhodujícím činitelem pro zvládnutí náročné situace a podmínkou úspěšné integrace (Kukla, 2016) např́klad s ohledem na budoucí studijní a pracovní možnosti.

Přestože je jazyk hostitelské společnosti důležitým předpokladem pro přijetí nového člena do společnosti, ani ovládání jazyka neznamená vždy bezpodmínečné přijetí. Podle Jarkovské a kol. (2015) ani dokonalé zvládnutí jazyka, které bývá běžné, nedělá z „cizince“ „našince“ - spíše se stane Čechem „jen jako“. Migranti používají různé strategie, jak se vymanit z takových podob jinakosti, které jsou pro úspěšné soužití nežádoucí a které, jak ukazuje i náš výzkum, mohou být velmi subtilní (tř̌eba na rozdíl od silně zvýrazněné etnicity romské, viz Jarkovská et al., 2015). V zásadě v našem výzkumu pozorujeme dvě klíčové strategie. Jednou strategií je zdůrazňování normálnosti ve smyslu stejnosti s majoritou a druhou je využití repertoáru vlastních kvalit, kdy se migranti snaží vytěžit co nejvíce ze svých silných stránek a tím získat ocenění ve skupině. Obě strategie lze samozřejmě využít společně, ačkoliv první se spíše bude bližit asimilační praxi a druhá dává větší prostor pro integraci. Nedomníváme se, že tento repertoár strategií je kompletním výčtem, jak i naznačuje konceptualizace Berryho a kol. (2002) zahrnující i marginalizaci a separaci, nicméně se jedná o strategie, ke kterým jsme získaly v našem výzkumu nejvíce podrobností a které budeme podrobněji ilustrovat $\mathrm{v}$ následujícím textu. $\mathrm{V}$ další části se tedy podíváme na témata představující další výzvy, kterým začleňující se migranti čelí a které souvisí s jejich jinakostí. Pro zvládnutí souvisejících situací v našem příkladu využívají právě výše uvedené strategie. 


\subsection{Zranitelnost}

Dalo by se konstatovat, že at' už se dítě-cizinec snaží dělat cokoliv, aby vypadalo stejně jako ostatní, přesto často vyplave na povrch jeho jinakost. V důsledku projevů jinakosti se často spolužáci (majorita) vůči dítěti-migrantovi projevují negativně formou nejapných poznámek, v horším případě posmívání či jiných forem psychické šikany (Janošová et al., 2016). Z rozhovorů jasně vyplynulo, že se všichni respondenti s takovými poznámkami běžně setkávali a nebylo $v$ jejich silách je ignorovat. $V$ některých případech to vedlo až k silným pocitům méněcennosti, vlastní nedostatečnosti. Šikana vzniká v procesu mezilidských interakcí, do něhož vstupuje celá řada aspektů na úrovni jedince, trrídního kolektivu sociálních norem a dostupných diskursů (Zábrodská, 2016). My si na konkrétních příkladech ukážeme, jak do tohoto procesu vstupuje jinakost spojená s jiným původem či nedostatečnou znalostí jazyka.

Jako setkávala jsem se s takovýma těma narážkama, jako že „ty seš z Ukrajiny“ a tak, a vím, že mě to hrozně trápilo, že jsem jiná... Že jsem si hrozně přála, proč jsem se nenarodila tady, proč nemám český rodiče a fakt jsem s tím jako hodně bojovala... Prostě něco takovýho tam bylo. (Inna, 24 let, studentka VŠ)

$S$ těmito pocity značně zápasil nejeden z našich respondentů. Dokonce se objevovala přání úplně vymazat svou historii, své kořeny. To vše kvůli tomu, že stejnost, zapadnutí, bylo vnímáno jako žádoucí hodnota, pokud chtějí ve své bezprostřední vrstevnické skupině být akceptováni. To, kde se člověk narodil (resp. odkud pochází jeho rodina), zde hrálo ústřední roli - přitom se jedná právě o jednu z mála charakteristik, která nám byla určena a kterou nemůžeme ovlivnit. Zdánlivě neškodné poznámky, které však nelze zlehčovat, tedy vedly $\mathrm{k}$ významným změnám vnímání vlastního původu a hlavně sebe sama. $\mathrm{V}$ podobném duchu mluvila jedna z respondentek i o své sestře, již narozené v ČR, která současně chodí na základní školu.

Takže ona ted' pokaždý, když jsme mezi Čechama, tak okamžitě přepne na češtinu a prostě nebaví se s náma ukrajinsky vủbec. [...] Nedávno byla u nás sousedka Češka, kecaly s mámou o kytkách na balkoně a odemykala jsem dveře a přišla Táňa - ségra - a prej „Naty, Naty, nemluv ted” ukrajinsky, je tu sousedka“. A takže ona se za to jako vyloženě stydí a mám pocit, že pak úplně přestane chtít mluvit. (Natália, 24 let, studentka VŠ) 
Na tomto příkladu je jasně vidět, že i pro sestru je „být stejná“ významnou kvalitou, at’ už jí to bylo naznačeno přímo, nebo to nepřímo vytušila $\mathrm{z}$ interakcí ve škole. A i přes to, že v ČR narozená Táňa (sestra respondentky) má dospělou integrovanou sestru a rodiče žijí v Čechách již skoro 25 let, tato rodinná situace nebyla vnímaná s respektem, jako úspěch. Naopak, stále byla potenciálním rizikem určité sociální exkluze. Zneviditelnění a splynutí s většinou se jevilo jako emocionálně bezpečná strategie. Vojtíšková (2012) tuto praxi pozoruje specificky u některých etnických skupin, a to konkrétně u žáků ruského či vietnamského původu, což může být spojeno se silnou snahou k naplnění motivace k vzestupné sociální mobilitě.

$\mathrm{Z}$ našich zjištění nicméně plyne, že děti-migranti mají vyšší šance stát se obětí různě závažné šikany, což ukazují i zkušenosti našich respondentů. Většinou se jednalo o tzv. psychickou šikanu typu poštuchování, provokování, urážek týkajících se vzhledu, oblékání, či původu. $V$ jednom případě šlo dokonce i o zastrašování a fyzické násilí. Takto popisují svoje zkušenosti naši respondenti:

Tam byla jedna holka, Karla se jmenovala. No a ta byla jako... taková jako zlá. Jakože měla zlý myšlenky a zlý potřeby. No a tím, že jsem jako byla v tom prostředí nová a neuměla jsem jazyk a tak, tak jsem byla v takovým jako oslabeným postavení, tak si mě vybrala... aby měla nějakou jako obět'... Protože ona jako měla radost z toho, když ji lidi poslouchali a dělali, co chce a tak. No a tím, že jsem ze začátku neměla žádný kamarády, tak ona, že se se mnou chce jako kamarádit, takže jsme spolu kamarádily... No ale sem tam byla taková jako že zlá... a měla takovýho velkýho psa... ovčáka... a vyhrožovala mi několikrát, že na mě pustí toho psa, kterej vypadal fakt docela zle, hrozně štěkal, aby mě jako pokousal. (Lídia, 29 let, absolventka VŠ)

Jste Tataři... a bla bla bla, že jsem z Ukrajiny a na Ukrajině tohle a tamto... a Černobyl, že jako jsem mutant... a prostě podobný věci. Bylo toho hodně no. (Natália, 24 let, studentka VŠ)

Jen na mě měli kecy... takže to byly poznámky typu Rusáku, táhni na Ukrajinu (...) další Ukrajinec, Rusák ze stavby přišel... A máte tam na Ukrajině vůbec elektřinu? (Denis, 24 let, student VŠ)

Z rozhovorů bylo patrné, že se jich tyto projevy vždy dotýkaly. Nicméně je třeba konstatovat, že pochopitelně i samotní respondenti reflektují, že sama odlišná státní příslušnost či jejich migrační zkušenost nebyla tím jediným a zásadním důvodem k šikaně. Nutno ale říci, že je jejich cizí původ, 
konkrétně ze země bývalého Sovětského svazu, které dle jejich názoru mnoho Čechů kvůli nedávné historii nemá v lásce, stavěl do nevýhodné pozice, z níž se jen těžko vymaňuje. Přívlastky jako „okupanti z Ukrajiny“ atd., které respondenti zmiňovali, jsou toho jasným příkladem. Ukazuje se, že migrační zkušenost a nutnost aktivní adaptace do nového školního prostředí po př́ijezdu do České republiky způsobuje, že se dítě ocitá ve zranitelném postavení. Ve vztazích se může chovat nejistě, či dokonce odtažitě, jak jsme si ukázali v úvodu, nerozumí řadě situací a do toho se střetává se situací, že přichází ze země, která není v našem prostoru vnímána jako žádoucí. To vše přispívá ke zvýšené vulnerabilitě.

V našem př́ipadě se všichni respondenti z této podoby šikany dokázali vymanit. Popisují situace, v nichž už ve chvílích největšího tlaku své podřízené postavení neustáli a začali se bránit. Touto obranou ustaly útoky mířené proti jejich osobě, byla však nutná jejich aktivita a potřebné sebevědomí k tomu, aby útoky svým směrem zastavili. Ukázali svou hodnotu a schopnosti, a sami tak pochopili svoji cenu a vydobyli si určité postavení, jak ilustruje např́íklad následující výrok:

Takže jsem pochopila, že se člověk musí jako ozvat, aby se mu to nestalo znova. Že se tím jakoby zastaví forma nějakýho nátlaku nebo ubližování, at' fyzickýho, nebo psychickýho, když se tomu člověk postaví. (Natália, 24 let, studentka VŠ)

Jako úspěšná strategie, jak zapadnout do kolektivu v české třídě, se jeví snaha o splynutí s většinou, nevybočení z řady, a tedy, jak jsme pojmenovaly výše, strategie zdůrazňování normálnosti. Neustálé přizpůsobování a adaptování se tak stává u dětí migrantů jakýmsi základem fungování v každodenních interakcích. Jinakost sama o sobě může přinést negativní pozornost nebo vyloučení, o to větší riziko znamená jakékoliv její zvýraznění. Tuto v zásadě asimilační praxi (Berry et al., 2002) potvrzuje i výzkum školního prostředí, v němž je upozorňováno na to, že úspěch dítěte je hodnocen skrze jeho asimilační schopnost. Na základě kvalitativních rozhovorů s učiteli, kteří ve svých tř̌́dách vyučují i žáky z různých kulturních prostředí, se jeví, že v očích učitelů je úspěšně integrovaný migrant zbaven etnických specifik (Machovcová, 2017). Jinakost je chápána jako slabina a úspěchem je odstranění (viditelné) jinakosti, zejména tedy v mluvené řeči, což je chápáno jako cíl začleňování umožňující dítěti zapojit se plně ve vztazích a uspět akademicky (Jarkovská et al., 2015; Machovcová, 2017). Jak jsme se již zmínily výše, naši respondenti se setkali s negativními reakcemi na svou osobu ve formě výsměchu 
či urážek. $V$ rozhovorech tak došlo i na téma šikany a jak se ukázalo, většina z respondentů $s$ ní má neblahé zkušenosti. 0 šikaně obvykle mluvíme tehdy, jedná-li se o opakované záměrné ubližování a je-li obět’ bezbranná či slabá pro nějakou svou odlišnost, at' už fyzickou, či psychickou (Říčan, 1995). Janošová a kolegyně (2016) upozorňují na to, že jedním z velkých témat je právě konstrukce odlišnosti šikanovaných dětí. Děti, které se nějak odlišují od ostatních, jsou skupinou vnímány jako divné a jsou z kolektivu vylučovány, mimo jiné právě prostřednictvím šikany. Odlišnost těch, kteří jsou šikanovaní, představuje podle mnoha sociokulturních studií hlavní důvod, kterým děti šikanu opodstatňují a omlouvají. Hamarus a Kaikkonen (2008) ve své studii poukazují na to, že děti ve výzkumu uvádějí jako hlavní důvody šikany nesmělost, citlivost, dále třeba staromódní oblékání a mimo jiné také etnicitu a náboženské vyznání. Všechny tyto aspekty pochopitelně nelze chápat výhradně jako otázku trvalých individuálních charakteristik jednotlivců, ale v kontextu konkrétních mezilidských interakcí a socio-kulturního prostředí (Zábrodská, 2016).

Z našeho pohledu je zajímavá situace u jediného respondenta, který své zkušenosti jako šikanu neinterpretoval, ačkoliv se s řadou podobných poznámek také setkal a lze konstatovat, že se jednalo o formu psychické šikany (Janošová et al., 2016). Na rozdíl od ostatních, směřujících spíše k asimilaci do českého prostředí či jakési uhlazené nebo částečně zastřené duální identitě, se u něj projevila poměrně silná etnická identita ve vztahu k zemi původu. Ve své výpovědi se za svůj ukrajinský původ nestyděl, nijak ho nezastíral. Poznámky ostatních si nikdy nebral př́liš k srdci, byl si vědom svých dobrých vlastností a měl dostatečnou národní hrdost, což nemohlo být narušeno nejapnými poznámkami dětí, které o jeho zemi vlastně nic nevěděly. Takové pojetí etnické identity spolu s osobními aspekty psychické odolnosti pomohly náročnou situaci překonat a nepřikládat jí př́liš vysokou důležitost.

\subsection{Podceňování potenciálu nově príchozích}

Dalším z náročných okamžiků, které může jinakost přinést, bylo podceňování druhými. Toto podceňování se týkalo hlavně intelektových schopností a charakteru respondentů. $Z$ výpovědí vyplývá, že jim často byly kvůli jejich původu přisuzovány nedůvodné nebo stereotypní charakteristiky. Jedna respondentka např́klad popisovala rozhovor se svou kamarádkou, při kterém jí oznámila, že se s ní kvůli zákazu rodičů nemůže bavit. „Ukrajinci jsou blbý, tak se se mnou nemá bavit, aby neměla špatný známky." Podobná příhoda se 
jí stala i s jinou spolužačkou, která si od ní odsedla poté, co zjistila, odkud pochází, „aby ji náhodou neokradla“. V takových chvílích se samozřejmě člověk cítí, jako by neměl žádnou hodnotu, a jako dítě dané situaci vůbec nerozumí. Dvě $\mathrm{z}$ respondentek dokonce $\mathrm{v}$ rozhovoru explicitně vyjádřily, že $\mathrm{v}$ té době litovaly svého původu a přály si být Češkami. Dále jedna z respondentek líčila situaci při vyučování.

No první rok se mi všichni smáli, protože jsem nerozuměla, že jo... Takže mě všichni šikanovali, ukazovali si na mě, že jsem hloupá... Pamatuju si, že nám třeba učitelka řekla: „Přineste si na zítra... nevim... šípek a budeme kreslit šípek“ a já jsem nevěděla, že mám něco takovýho přinýst, protože jsem nerozuměla. Takže všichni přinesli šípek, a já ne. Takže jsem byla prostě za nějakou retardovanou. A takhle podobně děti jako reagovaly, protože ve čtvrtý trrídě jsou děti docela jako zlý. (Natália, 24 let, studentka VŠ)

$\mathrm{Na}$ tomto příkladu je přesně vidět, jak někdy učitelé svou práci podcení ve snaze přistupovat ke všem žákům stejně a bez rozdílů, jak to zmiňují Jarkovská a kol. (2015), a do situace neintervenují, i když by to mohlo být na místě. Podobné je to i u dalšího příkladu.

Museli jsme používat tornádo [typ psacího pera]. A paní učitelka nám psala nějakej vzkaz na tabuli jako pro rodiče... A já jsem si to jako psala do notýsku, ale vůbec jsem nevěděla, jak to mám jako psát. Vủbec jsem neuměla psací písmo, jenom tiskací ćíst. A na tý tabuli to bylo psace a já jsem vůbec nechápala, co to je... Třeba písmeno $S$ jsem vůbec nevěděla, jak mám napsat... A tak jsem ten vzkaz psala asi hodinu, co měly děti napsaný za chvíli... A všechno se mi to rozpilo tím tornádem v tom notýsku, jak mi to trvalo dlouho a dlouho jsme to držela na tom papíre, že pak ten vzkaz vůbec nešel přečíst. (Lídia, 29 let, absolventka VŠ)

I zde je zřetelné, jak moc by těmto dětem prospěla individuálnější péče ze strany učitele. Stačila by častější kontrola sešitů, ujištění o porozumění úkolu nebo doučování - možností je spousta. Některé z těchto drobných problémů dnes mohou být snadněji řešitelné s využíváním online systémů správy školní agendy, nicméně faktem zůstává, že děti s migrační zkušeností se mohou dostávat do pro ně prakticky i emocionálně náročných situací, kdy si připadají vyčleněné a izolované. Ochota se ozvat a vyžádat si pomoc, která nebyla nabídnuta, může být vnímána jako zdůraznění jinakosti v nežádoucí formě, a proto nelze vždy očekávat, že žák-cizinec v nesnázích s důvěrou o pomoc požádá, a pokud ne, tak není třeba do situace aktivně vstupovat. 
Dle respondentů bylo velice těžké se z podceňované pozice vymanit, nicméně se to po nějaké době podařilo, a to vesměs skrz přizpůsobení se podmínkám okolí, což pochopitelně mohlo ubírat na jejich autenticitě a tak i na sebevědomí. Když měli naši respondenti popsat, jací ve škole byli, volili slova jako slušní, stydliví, přizpůsobiví nebo hodní, což vcelku dokresluje pohled, který jsme nastínili výše, tedy snahu „zapadnout“.

Druhým možným postupem bylo dostat se ke druhým skrze repertoár vlastních kvalit. Což už tedy vyžadovalo dobrou znalost situace a uvědomění si jednak svých dovedností, jednak jejich ocenění vrstevníky. Takto popisovala jedna z respondentek, jak probíhalo její začleňování po zážitku s šikanou.

Učila jsem se docela dobře, takže když jsme pak jeli třeba do Francie, tak jsem uměla třeba nejlíp francouzsky z tý naší skupiny, takže jsem měla kolem sebe víc těch Francouzů a že jsem je tak jako, ne vedla, ale měla jsem kolem sebe víc těch kamarádů. A už mě prostě začali brát jako sobě rovnou no. (Natália, 24 let, studentka VŠ)

Jo... to jo, s dětma jsem si rozuměla. Já jsem hrozně hezky kreslila, takže možná díky tomu jsem se k nim tak jako dostala... Vždycky ke mně někdo přišel, že chce něco nakreslit, tak jsem mu to nakreslila. Ale tak taky to trvalo. (Inna, 24 let, studentka VŠ)

Aby respondentka Natália získala své rovné postavení, musela se v první řadě umět ozvat. Jak je vidět zde, dalším aspektem funkčnosti jejích vztahů byl její dobrý školní prospěch, zejména dobrá znalost francouzštiny, která se jí vyplatila na školním výletě. Stejné způsoby získání své pozice mezi ostatními popisovali i ostatní ( $\mathrm{v}$ textu např. Inna) - jednalo se právě o mechanismy jako školní úspěšnost a pomoc při testech, fotbal, kreslení a tak dále. Respondenti také popisují, že jakmile získali prvního kamaráda, šlo už vše snáze. Měli někoho, kdo by je podpořil, pomohl se začleněním, dodal jim vědomí vlastní účinnosti (self-efficacy).

S podobnou praxí se setkala ve své studii i Vojtíšková (2012) popisující takzvaný imigrantský paradox. Zatímco častý stereotyp spočívá v chápání migrantů jako nějakým způsobem problémových, náročnějších žáků, řada migrantů naopak svými výsledky předčí průměr třídy. Konkrétně ve své studii uvádí příklad žáka, který, ačkoliv nastoupil až do šesté třídy bez znalosti českého jazyka, za několik let vyhrál olympiádu z českého jazyka. Zde tedy také poukazuje na mechanismus zapojení do kolektivu, který spočívá v co 
nejvyšší míře využití osobního potenciálu jednotlivce $\mathrm{k}$ tomu, aby dosáhl nějakým způsobem prestižní, majoritou oceňované pozice.

\section{Diskuse a závěr}

Přítomnost žáků cizinců na českých školách již není tak neobvyklou realitou. Práce s těmito žáky klade specifické nároky na učitele a v zásadě vyžaduje zejména z počátku velmi individuální a kulturně citlivý přístup. Nicméně například z výzkumu Jarkovské a kolegyň (2015) vyplývá, že učitelé nevnímají práci s etnicky smíšenou třídou jako nějak významně specifickou, praktická podpora je zaměřována zejména na osvojení českého jazyka, ale málokdy pozornost učitelů systematicky přesahuje jazykový rámec. To sice nemusí znamenat, že $\mathrm{v}$ praxi neposkytnou individualizovanou podporu i $\mathrm{v}$ dalších oblastech, nicméně problém může být právě v nedostatečně komplexním vyhodnocení nároků a specifik prožívání dítěte, které právě přicestovalo. Praxe u nás, se kterou se setkala i část respondentů, je taková, že žák-cizinec bývá zařazen do nižšího ročníku, než by odpovídalo jeho věku. ${ }^{4}$ Může se také stát, že učitel využije možnosti žáka v prvním pololetí neklasifikovat, $v$ narůstající míře školy využívají asistenty, v lokalitách $s$ více migranty bývá lépe dostupná výuka češtiny jako cizího jazyka, a to i v podobě prázdninových kurzů (viz např́íklad praktické a metodické materiály sdružení META - společnost pro př́ležitosti mladých migrantů5).

Otázkou nicméně zůstává, v jakém prostoru jsou tato opatření realizována. Jak je v české škole konstruována stejnost a jinakost, jaké hodnoty jim jsou přisuzovány, jaké konstelace vlastností jsou výhodné a jaké nevýhodné? V našem výzkumu jsme poukázaly na náročnou emociální situaci dětí původem z Ukrajiny, které se chtěly aktivně zapojit v české škole. Vidíme zde různé polohy - obavy na sebe upozornit, zvýšenou zranitelnost související s jinakostí a snahu tuto situaci vybalancovat prostřednictvím co nejlepšího zapadnutí založeného na „normálnosti“ definované majoritou a ideálně nalezení vlastních silných stránek, které mohou být oceňovanou formou jinakosti. Jak píše Burman (2008), pokud jsme v našich přístupech slepí ke kulturním odlišnostem, pak nedokážeme vnímat, jak se vzorce chování menšin vždy vztahují k tomu, jak se chová majorita. Riskujeme tak určitou esencializaci chování

4 Na tuto praxi reaguje např́klad portál Inkluzivní škola: http://www.inkluzivniskola.cz/ organizace-integrace-cizincu/zarazeni-do-rocniku

5 META - společnost pro př́ležitosti mladých migrantů: http://www.meta-ops.cz/metodickea-vyukove-materialy 
menšin jako jejich nevyhnutelnou a neměnitelnou vlastnost a zakrýváme fakt odlišné startovní dráhy.

Předložený výzkum doplňuje a posiluje zjištění dalších v Česku realizovaných studií (Jarkovská et al., 2015; Machovcová, 2017) a ukazuje na to, s čím do situace vstupují děti s migrační zkušeností a jak interpretují reakce většiny na svou osobu. Nesmělé pokusy o spolupráci, přehlížení potřeb „protože se nikdo aktivně nehlásil o pomoc", riziko podceňování, vyhýbání se diskusi o odlišnostech. Zvládnutí vlastní jinakosti vyžaduje silné osobní zdroje. Ve zde prezentovaném př́padě je usnadněno konkrétní etnickou skupinou disponující jazykovou i kulturní blízkostí a právním postavením umožňujícím získat občanství. V datech jsme identifikovaly dvě klíčové strategie zvládání jinakosti. V prvním př́padě se jednalo o zdůrazňování normálnosti, tedy snahu ukázat své „zapadnutí“ do majority, např́klad zvládnutím jazyka, omezením používání mateřského jazyka, nebo vymezením se oproti určitému napadání, a tedy snahu uchopit svou pozici ve třídě jako plnohodnotný člen skupiny. Druhou strategií, kterou jsme také ilustrovaly výše, bylo využití vlastních předností a snaha získat dobré vazby v kolektivu díky tomu, že je možné prezentovat nějakou specifickou a skupinou oceňovanou dovednost (např. zvládnutí cizího jazyka, který třída společně studuje, výtvarný talent), či dokonce ostatním na jejím základě pomoci.

Zvládnutí zapojení do nového kolektivu je pro děti-cizince náročnou emociální prací na sobě. Naši respondenti, soudě podle faktorů, jako je např́klad dosažené vzdělání, uspěli. Jejich výpovědi jsou však určitým dokladem toho, jak jednocestná integrace může být - v podstatě se, at' už explicitně, nebo implicitně, ze strany majority očekává přizpůsobení se cizinců domácím. Dále naši respondenti naznačují, jakým směrem je třeba měnit prostředí českých škol, tak aby bylo více inkluzivní, a ne a priori nastavené na očekávání asimilace maskované za integraci. Z našich zjištění vyplývá důležitost porozumění emocionální situaci dítěte, pochopení, že i ono je nějakým způsobem „vyvedeno" z míry a jeho chování tak může být i pro něj neobvyklé. Je vhodné podrobněji studovat faktory odolnosti, které umožňují zvládat i vypjaté situace, jež lze nazvat šikanou. Dalším zajímavým aspektem je i způsob nabízení podpory - očekávání, že dítě přijde samo, pokud má obtíže, oproti aktivnímu vstupu do situace ze strany učitele. Požádání o pomoc, jak jsme zmínily výše, může být ze strany dítěte vnímáno jako nevhodné zdůraznění jinakosti. Dále je zde potřeba otevřené diskuse o kulturních odlišnostech, která by měla stát na vzájemném respektu vůči jiným kulturám. $\mathrm{Z}$ pedagogického 
hlediska pak jde zejména o snahu zvládnout období nedostatečné znalosti domácího jazyka (např. pomůcky, informace pro rodiče), podporovat jiné formy komunikace s učitelem i tř́́dou (původní jazyk, druhý jazyk, který se celá třída učí aj.). Pro další výzkum by bylo zajímavé podívat se také na zkušenosti ve školách více zaměřených na výuku jazyků, zda i v takovém prostředí, kde je běžnější mluvit více řečmi, bude hrát osvojení majoritního jazyka významnou roli pro integraci žáků do života školy.

Z teoretického hlediska jsme pro náš text zvolily jako výchozí Berryho přístup $\mathrm{k}$ akulturaci. Pochopitelně i tento přístup má svá omezení, která je vhodné vzít v potaz v dalších studiích. Konkrétně bývá tomuto přístupu vytýkáno, že je př́liš generalizující a nedokáže podrobněji zachytit osobní a kontextuální specifika akulturačních procesů (Lazarus, 1997; Schwartz et al., 2010). Jak jsme již naznačily v empirické části, pozornost je také třeba věnovat tomu, jak k situaci mohou přistupovat různé etnické skupiny, ale pochopitelně i lidé v různé fázi života a $s$ jinými předchozími zkušenostmi. To vše je výzvou pro další výzkumy zaměřené na otázku utváření jinakosti a stejnosti ve školním prostředí.

\section{Literatura}

Berry, J. W. (1997). Immigration, acculturation, and adaptation. An International Review, 46(1), 5-68.

Berry, J. W., Poortinga, Y. H., Segall, M. H., \& Dasen, P. R. (2002). Cross-cultural psychology. Research and applications. Cambridge: Cambridge University Press.

Braun, V., \& Clarke, V. (2006). Using thematic analysis in psychology. Qualitative Research in Psychology, 3(2), 77-101.

Burman, E. (2008). Deconstructing developmental psychology. Hove: Routledge.

Čeněk, J., Smolík, J., \& Vykoukalová, Z. (2016). Interkulturní psychologie. Vybrané kapitoly. Praha: Grada.

Český statistický úřad. (2017). Cizinci v České republice 2017. Dostupné z https://www. czso.cz/documents/10180/45709982/29002717.pdf/770a1c14-6ea7-4c47-831e$3936 \mathrm{e} 3 \mathrm{ca} 1 \mathrm{ab} 3$ ?version $=1.2$

Čižinský, P., \& Hradecká, P. (2012). Dočasná pracovní migrace jako součást migrační politiky státu. Dostupné z http://migraceonline.cz/cz/e-knihovna/docasna-pracovni-migracejako-soucast-migracni-politiky-statu

de Wal Pastoor, L. (2015). The mediational role of schools in supporting psychosocial transitions among unaccompanied young refugees upon resettlement in Norway. International Journal of Educational Development, 41, 245-254.

Drbohlav, D. (2003). Současná migrace Ukrajinců a Rusů do Česka - podobnosti a rozdílnosti. Dostupné z http://migraceonline.cz/cz/e-knihovna/soucasna-migrace-ukrajincu-a-rusudo-ceska-podobnosti-a-rozdilnosti 
Hamarus, P., \& Kaikkonen, P. (2008). School bullying as a creator of pupil peer pressure. Educational Research, 50(4), 333-345.

Iljuk, B. (2016, ř́ijen). Identita migrantů a reemigrantů českého původu na začátku 21. století. Př́spěvek prezentovaný na konferenci Tři vlny reemigrace krajanů do vlasti: přínos a perspektivy - celostátní setkání k 25. výročí návratů černobylských krajanů do staronové vlasti, Litoměřice.

Janošová, P., Kollerová, L., Zábrodská, K., Kressa, J., \& Dědová, M. (2016). Psychologie školní šikany. Praha: Grada.

Jarkovská, L., Lišková, K., Obrovská J., \& Souralová, A. (2015). Etnická rozmanitost ve škole: stejnost v různosti. Praha: Portál.

Kukla, L. (2016). Sociální a preventivní pediatrie v současném pojetí. Praha: Grada Publishing.

Lazarus, S. R. (1997). Acculturation isn't everything. Applied Psychology, 46(1), 39-43.

Leontiyeva, Y., \& Nečasová, M. (2009). Kulturně blízcí? Integrace přistěhovalců ze zemí bývalého Sovětského svazu. In M. Rakoczyová \& R. Trbola (Eds.), Sociální integrace přistěhovalců v České republice (s. 117-160). Praha: Sociologické nakladatelství SLON.

Leontiyeva, Y. (2014). The education-employment mismatch among Ukrainian migrants in the Czech Republic. Central and Eastern European Migration Review, 3(1), 63-84.

Machovcová, K. (2017). Czech elementary school teachers' implicit expectations from migrant children. International Journal of Educational Development, 53, 92-100.

Ministerstvo vnitra. (2018). Celostátní setkání krajanů-reemigrantů. Dostupné z http://www. mvcr.cz/clanek/celostatni-setkani-krajanu-reemigrantu.aspx

Říčan, P. (1995). Agresivita a šikana mezi dětmi: jak dát dětem ve škole pocit bezpečí. Praha: Portál.

Schwartz, S. J., Unger, J. B., Zamoanga, B. L., \& Szapocznik, J. (2010). Rethinking the concept of acculturation: Implications for theory and research. American Psychologist, 65(4), 237-251.

Uherek, Z. (2005). Migrace a formy soužití v cílových prostorech. In T. Hirt \& M. Jakoubek (Eds.), Soudobé spory o multikulturalismus a politiku identit (s. 258-274). Plzeň: Vydavatelství a nakladatelství Aleš Čeněk, s.r.o.

Uherek, Z. (2016, ř́ijen). Reemigrace krajanů z Ukrajiny a Kazachstánu ve světle dat získaných Etnologickým ústavem $A V \check{C} R$. Příspěvek prezentovaný na konferenci Tři vlny reemigrace krajanů do vlasti: přínos a perspektivy - celostátní setkání k 25. výročí návratů černobylských krajanů do staronové vlasti, Litoměřice.

Vaculík, L. (1997). Dějiny volyňských Čechů I (1868-1914). Praha: Sdružení Čechů z Volyně a jejich přátel.

Vedder, P. H., \& Horenczyk, G. (2016). Acculturation and the school. In D. L. Sam \& J. W. Berry (Eds.), The Cambridge handbook of acculturation psychology. Cambridge: Cambridge University Press.

Vojtíšková, K. (2012). Vzdělávání dětí cizinců na pražských základních školách. Naše společnost, 2, 10-19.

Zábrodská, K. (2016). Sociokulturní přístup ke školní šikaně. In P. Janošová, L. Kollerová, K. Zábrodská, J. Kressa, \& M. Dědová (Eds.), Psychologie školní šikany (s. 41-58). Praha: Grada. 


\title{
I watched them playing and speaking a language that I didn't take in: Otherness and children with migration experience
}

\begin{abstract}
In this article, we aim to present the experiences of pupils with the perception of otherness in the classroom. Specifically, we will focus on understanding the experience of 1.5 generation of young immigrants from Ukraine. Our respondents, currently young adults, reflect in the interviews their experience of integrating into the Czech society. For the article we focus on their early school experiences. The research is based on interviews with four respondents, who were young people aged 24-29 living in the Czech Republic who moved to the Czech Republic from Ukraine aged 6 to 9 years. The interviews were analyzed using a thematic analysis (Braun \& Clarke, 2006). The aim of the presented text is a detailed analysis of the experiences with socialization at secondary school with an emphasis on the formation of otherness and sameness in the peer group. The analysis corresponds with the time axis of gradual integration into the Czech society from the initial "crash" to mastering and dealing with the demands of the personal situation. We will focus on the identified aspects of this process and the coping strategies. The rich data from the interviews show how the (non) knowledge of language is influential in the construction of otherness and, as with our respondents, even the relatively short period of time required to master local language, brings with it emotionally demanding experiences of exclusion from the group, isolation. In the classroom, these children were often mocked and even their intelligence belittled due to imperfect knowledge of the language. Interviews show that teachers rarely intervened, even though they could at least mitigate the negative development if not completely prevent some of the behaviors. After acquiring host country language it has been easier for the newcomers to build relationships with peers. We observe the desire to emphasize the sameness, and the strategy of inclusion through the repertoire of own qualities. As the most successful and in principle expected in the Czech education seems to be the strategy of assimilation, i.e. merging with the majority (Berry et al., 2002). The constant adaptation and re-adaptation of migrant children is a kind of basis for their day-to-day interactions.
\end{abstract}

Keywords: otherness, norm, minority, ethnicity, migration experience

\section{Autoři}

Bc. Nad’a Kabancová, Univerzita Karlova, Pedagogická fakulta, Ústav profesního rozvoje pracovníků ve školství, Magdalény Rettigové 4, Praha 1, 11639 , e-mail: kabancova.nada@gmail.com

Mgr. Kateřina Machovcová, Ph.D., Univerzita Karlova, Pedagogická fakulta, Katedra psychologie, Magdalény Rettigové 4, Praha 1, 116 39, e-mail: katerina.machovcova@pedf.cuni.cz 